\begin{tabular}{|c|c|c|c|c|c|c|c|c|c|}
\hline & $\begin{array}{l}\text { No in } \\
\text { group }\end{array}$ & $\begin{array}{c}\text { Median } \\
\text { age } \\
\text { (years) }\end{array}$ & $\begin{array}{c}\text { No }(\%) \\
\text { nulliparous }\end{array}$ & $\begin{array}{c}\text { Median } \\
\text { age at } \\
\text { menopause } \\
\text { (years) }\end{array}$ & $\begin{array}{c}\text { Median age } \\
\text { at onset of } \\
\text { symptoms } \\
\text { (years) }\end{array}$ & $\begin{array}{l}\text { Median age } \\
\text { at referral } \\
\text { (years) }\end{array}$ & $\begin{array}{l}\text { No }(\%) \text { who } \\
\text { had had } \\
\text { hysterectomy }\end{array}$ & $\begin{array}{l}\text { Median age at } \\
\text { hysterectomy } \\
\text { (years) }\end{array}$ & $\begin{array}{l}\text { Median time from } \\
\text { hysterectomy } \\
\text { to referral } \\
\text { (years) }\end{array}$ \\
\hline Osteoarthritis group & 292 & 58 & $52(18)$ & $49 \cdot 5$ & 49 & 53 & $82(28)^{\star}$ & 42 & 6 years \\
\hline Rheumatoid arthritis group & 270 & 59 & $71(27)$ & $49 \cdot 5$ & 48 & 50 & $39(14)^{\star}$ & 45 & 4 years \\
\hline Electoral register population & 243 & 50 & $33(14)$ & 50 & & & $37(15)$ & 43 & \\
\hline Local general practice population & 346 & 54 & $71(29)$ & 50 & & & $38(11)$ & 41 & \\
\hline
\end{tabular}

* Sixty three $(77 \%)$ and $25(64 \%)$ hysterectomies were carried out at least one year before referral to hospital in the osteoarthritis and rheumatoid arthritis groups respectively.

implied that the indications for surgery might be more important than surgery itself. There are several potential biases. Early symptoms in women with osteoarthritis may have been misinterpreted and resulted in hysterectomy. This is unlikely given the long median delay (six years) between operation and diagnosis and that those with spinal osteoarthritis did not have the greatest rate of hysterectomy. The difference in rate of hysterectomy between the women with osteoarthritis and those with rheumatoid arthritis may have been due to fewer gynaecological abnormalities occurring in those with rheumatoid arthritis. Previous studies found no difference between women with rheumatoid women with rheumatoid arthritis were similar to those in our population controls. By contrast, a link between hysterectomy and predisposition to osteoarthritis is biologically plausible. Dysfunctional uterine bleeding and fibroids, the main reasons for hysterectomy in our study, have both been attributed to an excess of oestrogens. ${ }^{3}$ Oestrogens have also been found to affect adversely several different animal models of osteoarthritis, ${ }^{4}$ possibly by affecting turnover of proteoglycan.

\section{Suppression of ovulation by transdermal oestradiol patches}

\author{
N R Watson, J W W Studd, A F Riddle, \\ M Savvas
}

Premenstrual Syndrome

Clinic, Department of

Obstetrics and

Gynaecology, Dulwich

Hospital, London

SE22 8PT

$\mathrm{N} R$ Watson, $\mathrm{MB}$, research

fellow

J W W Studd, MD, consultant gynaecologist

A F Riddle, MRCOG, senior registrar

M Savvas, MRCOG, senior registrar

Correspondence to: Mr Studd

Percutaneous oestrogen is a well tolerated and highly acceptable treatment for symptoms of the menopause. The percutaneous route avoids first pass liver metabolism and the associated changes in hepatic proteins ethinyloestradiol and mestranol, the oestrogens in the contraceptive pill thought to be associated with morbidity. This study was undertaken to determine the effect of transdermal oestradiol patches on ovulation.

\section{Patients, methods, and results}

Ten women attending this clinic (mean age 35 ) who had a regular cycle (28-30 days) and were not using arthritis and controls, ${ }^{2}$ and the rates of hysterectomy in

Our results suggest that although osteoarthritis undoubtedly has a multifactorial aetiology, an underlying imbalance of oestrogen may be responsible for both the gynaecological problems and the development, several years later, of osteoarthritis.

We thank the consultants in rheumatology and staff of the following for their cooperation and help: St Bartholomew's Hospital, The London Hospital, Homerton Hospital, Whipps Cross Hospital, Wanstead Hospital, St Andrew's Hospital, and Wapping Health Centre. We also thank Dr Eve Roman of the London School of Hygiene and Tropical Medicine for giving us access to data on the controls obtained from the electoral register.

1 Lawrence JS. Rheumatism in populations. London: Heinemann, 1977.

2 Short CL, Bauer W, Reynolds WG. Rheumatoid arthritis. Cambridge, Massachusetts: Harvard University Press, 195

3 Studd J, Thom MH. Oestrogens and endometrial cancer. In: Studd J, ed. Progress in obstetrics and gynaecology. Vol 1. Edinburgh: Churchil Livingstone, 1981:183-98.

4 Rosner IA, Goldberg VM, Moskowitz RW. Estrogens and osteoarthritis. Clin Orthop 1986;213:77-83.

(Accepted 10 June 1988

transdermal oestradiol patches every three days from the first day of menstruation for three cycles. Monitoring was by ultrasonography on alternate days and assay of luteal phase progesterone and oestradiol concentrations. When the study was completed the patients had an endometrial biopsy and were started on cyclical progestogens to correct excess endometrial proliferation.

The table summarises the results. During the that occur with oral treatment,' particularly with hormonal contraception were selected for the study. They were monitored for four cycles. The first cycle was without treatment to confirm ovulation. Subsequently they were treated with two $100 \mu \mathrm{g}$

Effects of transdermal oestradiol patches on ovulation

\begin{tabular}{lcllc}
\hline & Before treatment & 1st Month & 2nd Month & 3rd Month \\
\hline No who ovulated & 10 & 1 & & \\
No who menstruated (day) & $10(27-30)$ & $1 \star(28)$ & & Spotting \\
Mean (range) oestradiol $(\mathrm{nmol} / \mathrm{l})$ & $0 \cdot 37(0 \cdot 2-0 \cdot 5)$ & $0 \cdot 58(0 \cdot 2-0 \cdot 9)$ & $1 \cdot 1(0 \cdot 2-2 \cdot 9)$ & $0 \cdot 62(0 \cdot 3-0 \cdot 8)$ \\
Mean (range) progesterone $(\mathrm{nmol} / \mathrm{l})$ & $30 \cdot 1(13-81)$ & $2 \cdot 6(0 \cdot 2-7 \cdot 4)^{\star}$ & $0 \cdot 4(0 \cdot 1-1 \cdot 0)$ & $0 \cdot 4(0 \cdot 1-0 \cdot 9)$
\end{tabular}

^Progesterone concentration in the patient who ovulated was $34 \mathrm{nmol} / 1$. 
after the first implant. ${ }^{3}$ The rapid increase in oestradiol concentration and earlier suppression of ovulation that occur with patches suggest that they may be even more effective than implants; they are also easier to discontinue.

The avoidance of first pass liver metabolism is an advantage of patches as serious side effects or oral contraceptives have been attributed to altered hepatic function. Even with low dose pills adverse changes in lipoproteins have been reported, ${ }^{+}$yet with percutaneous preparations no measurable changes occur in lipids or in the clotting and fibrinolytic systems.' Though no epidemiological studies have shown that alterations in liver metabolism are detrimental, it seems prudent to prescribe treatment with the least effect on the liver. Another advantage of patches is that they only have to be changed twice a week.

As oestradiol patches are licensed for treatment of symptoms of the climacteric they would be ideal as a method of contraception for women over 35 and as treatment for women with cyclical problems of the premenstrual syndrome, which particularly occur in this age group. In clinical practice progestogens must be given for seven to 10 days each month to induce a withdrawal bleed to prevent endometrial hyperplasia.

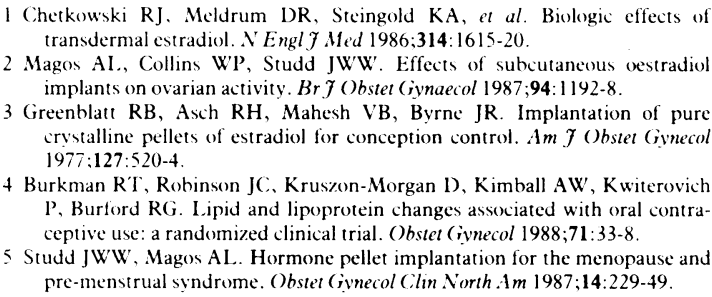

4 Burkman RT, Rohinson JC, Kruszon-Morgan D, Kimball AW, Kwiterovich P, Burford RG. Lipid and lipoprotein changes associated with oral contraceptive use: a randomized clinical trial. Obstet (innecol 1988;71:33-8.

5 Studd JW'W, Magos AL. Hormone pellet implantation for the menopause and pre-menstrual syndrome. Obstet (jynecol Clin North Am 1987;14:229-49.

Accepted $1+7$ ulv 1988

\section{Antibiotics carried in general practitioners' emergency bags}

\section{Edmund L C Ong, Edward M Dunbar}

Department of Infectious

Diseases and Tropical

Medicine, Monsall

Hospital, Manchester

M10 8WR

Edmund L C Ong, MRCP, registrar

Edward M Dunbar, MRCP, consultant

Correspondence to: Dr Ong

Numbers of respondents ( $n=$ 115) who carried various antibiotics in their emergency bags. All drugs were oral preparations unless indicated otherwise; figures in parentheses are numbers carrying parenteral preparations

\begin{tabular}{|c|c|}
\hline Antibiotic & No \\
\hline \multicolumn{2}{|c|}{ Penicillins } \\
\hline Ampicillin & $73(2)$ \\
\hline Amoxycillin & 34 \\
\hline Augmentin & \\
\hline Benzylpenicillin & $3(52)$ \\
\hline Flucloxacillin & 27 \\
\hline Phenoxymethylpen & 24 \\
\hline Benethamine penici & (2) \\
\hline \multicolumn{2}{|c|}{ Cephalosporins } \\
\hline Cephalexin & 15 \\
\hline Cephradine & 21 \\
\hline Cefaclor & 23 \\
\hline Cefadroxil & 1 \\
\hline Cefuroxime & 3 \\
\hline \multicolumn{2}{|c|}{ 4-Quinolones } \\
\hline Ciprofloxacin & 12 \\
\hline Nalidixic acid & 6 \\
\hline \multicolumn{2}{|c|}{ Sulphonamides } \\
\hline Co-trimoxazole & 79 \\
\hline Sulphadimidine & 1 \\
\hline Sulphadiazine & 1 \\
\hline \multicolumn{2}{|c|}{ Aminoglycosides } \\
\hline Gentamicin ${ }^{\star}$ & 1 \\
\hline Neomycin & 1 \\
\hline \multicolumn{2}{|c|}{ Others } \\
\hline Erythromycin & 112 \\
\hline Tetracycline & 34 \\
\hline Trimethoprim & 24 \\
\hline Metronidazole & 18 \\
\hline Chloramphenicolt & 12 \\
\hline Nitrofurantoin & 3 \\
\hline
\end{tabular}

\section{Methods and results}

We compiled a one page questionnaire containing lists of common antibiotics so that general practitioners could tick the ones that they kept in their bags. We posted this questionnaire, together with patients' discharge letters and letters from clinics, to general practitioners whose patients had attended this department between 1 March and 30 April 1988. The survey was anonymous, and we did not refer to the chief medical officer's letter.

Of the 180 questionnaires sent out, 115 were returned, giving a response rate of $64 \%$. The mean age of the general practitioners who responded was $41 \cdot 3$ years (range 26-67). One hundred of the respondents were principals (three trainers) and 15 trainees. Altogether 113 had antibiotics in their bags; two principals did not carry any. The mean number of antibiotics carried was $5 \cdot 3$ (range $0-14$ ). One hundred and nine respondents carried penicillin preparations and 56 parenteral penicillin. The most common antibiotic carried was oral erythromycin (112 doctors) followed by oral co-trimoxazole (79) and oral ampicillin (73) (table).

Of the 34 respondents who were members of the Royal College of General Practitioners, only 22 carried parenteral penicillin. One of the three trainers and six of the 14 trainees did not carry it.

We did not assess whether our respondents were typical of all general practitioners in Manchester.

\section{Comment}

We believe that this is the first study of the drugs that general practitioners keep in their emergency bags. We surveyed the range of antibiotics because we have become increasingly concerned that general practitioners are not aware that the use of parenteral penicillin in meningococcal infection before transfer to hospital, especially in the presence of a haemorrhagic rash, may be life saving. Previous inquiries indicated that deaths from meningococcal infections were due to delayed diagnosis and treatment. ${ }^{23}$

Our questionnaire was sent out less than four weeks after the chief medical officer's letter was posted to all doctors in the United Kingdom, and yet only $49 \%$ of our respondents had parenteral penicillin in their emergency bag. It might be argued that our survey was biased because we sent the questionnaires with patients' discharge summaries and follow up letters to clinics; such bias would mean that our results are an overestimate of the proportion of general practitioners keeping parenteral penicillin in their bag. Moreover, those who replied were likely to be more motivated and thus may have been atypical.

We are encouraged that most general practitioners $(98 \%)$ carried antibiotics. The overall abundance of cephalosporins $(53 \%)$ is worrying as it probably reflects common use in the community. Each general practitioner must decide which drugs he or she requires in the emergency bag; antibiotics such as parenteral benzylpenicillin should be included, and erythromycin, ampicillin, and co-trimoxazole are commonly also recommended. ${ }^{+}$

This study suggests that more needs to be done to educate general practitioners about the early use of parenteral penicillin in meningococcal infection. In the outbreak of meningococcal disease in Gloucestershire between October 1981 and March 1986 antibiotics were given before admission to hospital in only six out of 65 cases documented.' In another study none of the 86 patients who died from meningococcal infection received any intravenous antibiotics before arrival in hospital. ${ }^{2}$ Parenteral penicillin should be readily available for immediate administration.

We thank all those general practitioners who returned completed questionnaires. The survey was partly supported by the John Hamilton Fund.

1 Chief Medical Officer. Meningococcal infection: meningitis and septicaemio. London: Department of Health and Social Security, 1988. PL/CMO (88)2. 2 Slack J. Deaths from meningococcal infection in England and Wales in 1978 f $R$ Coll Physicians Lond 1982;16:40-4.

3 Oakley JR, Stanton AN. Meningococcal infection during infancy: confidential inquiries into 10 deaths. Br Med $\mathcal{F} 1979 ;$;i:468-9.

Moulds AJ, Martin PB, Bouchier-Hayes TAI. Emergencies in general practice. Lancaster: MTP Press Limited, 1983.

5 Cartwright KAV, Stuart JM, Noah ND. An outbreak of meningococcal disease in Gloucestershire. Lancet 1986;ii:558-61.

Accepted 21 fune 1988 